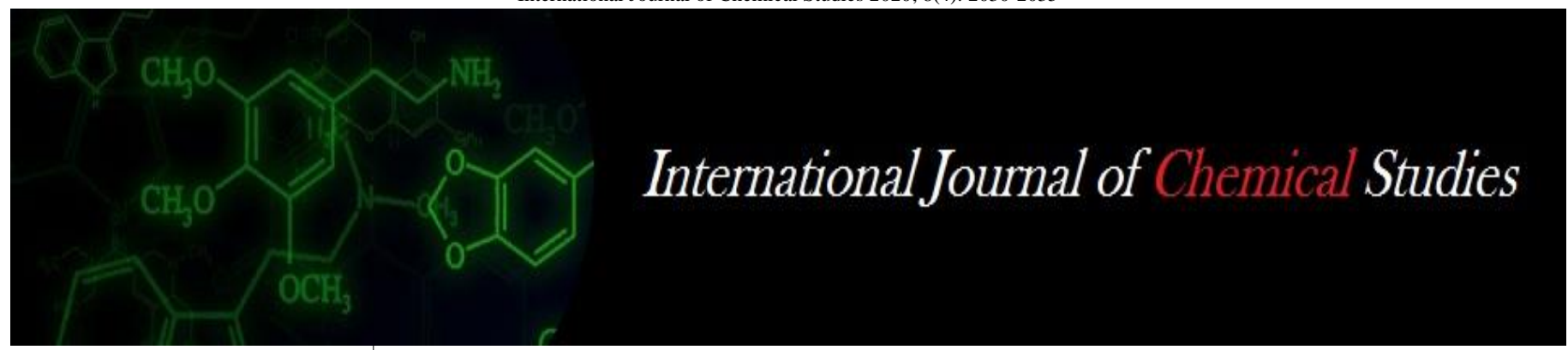

P-ISSN: 2349-8528

E-ISSN: 2321-4902

www.chemijournal.com

IJCS 2020; 8(4): 2030-2035

(C) 2020 IJCS

Received: 01-05-2020

Accepted: 04-06-2020

\section{Soumya Mishra}

Department of Plant Physiology, OUAT, Bhubaneswar, Odisha, India

\section{Monalisa SP}

Department of Crop Physiology. IAS, Siskhya ' $O$ ' Anusandhan

University, Bhubaneswar,

Odisha, India
Corresponding Author:

Soumya Mishra

Department of Plant Physiology,

OUAT, Bhubaneswar, Odisha,

India

\section{Physiological \& biochemical response of maize (Zea mays L.) to low grade rock phosphate under acidic soils of Odisha}

\section{Soumya Mishra and Monalisa SP}

DOI: https://doi.org/10.22271/chemi.2020.v8.i4v.9925

\begin{abstract}
A field experiment entitled was conducted at central farm OUAT, Bhubaneswar under Department of Soil Science \& Agricultural Chemistry during Kharif 2017. The physiological studies were carried out in the Department of Plant Physiology, College of Agriculture, Bhubaneswar. The result revealed that plant height, number of leaves and dry matter were improved by the level of $\mathrm{P}$ application. Among the treatments application of $100 \% \mathrm{P}(\mathrm{SSP})+0.2 \%$ LR registered significant increase in of the above growth character in maize crop which reflect a higher value of LAI, CGR, RGR and lower value of NAR. Chlorophyll content was found to be maximum in $\mathrm{T}_{7}(100 \%$ SSP $+0.2 \% \mathrm{LR})$ followed by $\mathrm{T}_{5}(50 \%$ $\mathrm{RP}+50 \% \mathrm{SSP})$. The other nutritional components like carbohydrate, protein and sugar of grains increased significantly with increase in the level of $\mathrm{P}$ application. Higher concentration of nutrient elements $(\mathrm{N}, \mathrm{P}$, $\mathrm{K}$ and S) found maximum in $100 \% \mathrm{SSP}+0.2 \% \mathrm{LR}$ in both grain and Stover. Among the different combination of RP and SSP, taller plant and highest no. of leaves were produced by application of 50\% $\mathrm{RP}+50 \%$ SSP with higher dry matter accumulation. The biochemical traits like nutritional composition (carbohydrate, protein \& sugar) found maximum with the application of 50\% RP+50\% SSP among the combined application. But in the combination of RP and SSP nutrient contents $(\mathrm{N}, \mathrm{P}, \mathrm{K} \& \mathrm{~S})$ found maximum with application of 25\% RP+75\% SSP in Stover and with the application of $50 \% \mathrm{RP}+50 \%$ SSP found maximum in grain. The grain yield in maize increased significantly with increase in the level of $\mathrm{P}$ application due to increase in cob weight, no. of grain per plant, cob length, cob diameter, 100 seed weight and the highest yield registered among the treatments by the application of $100 \% \mathrm{SSP}+0.2 \% \mathrm{LR}$. Among the combined application of $50 \% \mathrm{RP}+50 \%$ SSP registered the highest yield over the sole application of either R or SSP. In view of the positive and beneficial effect of $\mathrm{P}$ application in maize crop it may be concluded that improvement in productive of maize crop by the use of low grade rock phosphate under acid soils can be possible through combined application of 50\% RP + 50\% SSP.
\end{abstract}

Keywords: Phosphorous, SSP (Single super phosphate), RP (Low grade rock phosphate), LR (Lime requirement)

\section{Introduction}

Acid soils constitute about $30 \%$ of the total cultivable area in India. These soils are formed due to drastic weathering under hot humid climate and heavy precipitation. Acidic parent materials (granite), leaching of bases from the surface soils due to high rainfall, use of nitrogenous fertilizers like ammonium sulphate, ammonium nitrate, ammonium chloride and urea induces soil acidity. The acid soils are mostly distributed in Assam, Manipur, Tripura, Meghalaya, Mizoram, Nagaland, Sikkim, Arunachal Pradesh, West Bengal, Jharkhand, Orissa, Madhya Pradesh, Himachal Pradesh, Jammu \& Kashmir, Andhra Pradesh, Karnataka, Kerala, Maharastra and Tamil Nadu. It is estimated that about $12 \%$ soils are strongly acidic $(\mathrm{pH}<5.0)$, $48 \%$ moderately acidic ( $\mathrm{pH} 5.0-5.5)$ and $40 \%$ mildly acidic ( $\mathrm{pH}$ 5.6-6.5). Soil acidity and poverty are synonymous in the state of Odisha where $80 \%$ of soils are acidic. Low water holding capacity, high bulk density, and soil crusting along with chemical constraints like low $\mathrm{pH}$, low CEC, low base saturation (16 to 67\%), high Al, Fe and Mn saturation, and high Pfixing capacity ( 80 to $91 \%$ ) are major reasons for low crop productivity in such soils (Misra et al., 1989). Phosphorus is one of the most limiting nutrient in the soils of Odisha owing to $\mathrm{P}$ fixation and immobile nature of $P$ (Pattanayak et al., 2008). Acid soils fix two-to-three times more $\mathrm{P}$ per unit surface area than neutral or calcareous soil and the fixed $\mathrm{P}$ in acid soil is held with five times more bonding energy than calcareous soils. 
The extent of $\mathrm{P}$ fixation from the added $\mathrm{P}$ varies from $97 \%$ under air-dry condition to $76 \%$ under submerged condition, which is dependent on the type and quantity of clay minerals, sesquioxide and organic matter content (Pattanayak and Misra, 1989). Even though the soils of Odisha are low (27\%) to high $(73 \%)$ in soil available $\mathrm{P}$, crops grown in Odisha exhibited a significant yield loss due to omission of $\mathrm{P}$, which is $37 \%$ in hybrid rice (Pattanayak et al., 2008) and $49 \%$ in hybrid maize (Pattanayak et al., 2009). Thus, a proper $\mathrm{P}$ management strategy is required for improving and sustaining crop yields in the acid soils of Odisha. The right source of $\mathrm{P}$ application in acid soils depends on the nature of growing environment. Under submerged soil conditions, owing to relatively less $\mathrm{P}$ fixation and high solubility of native $\mathrm{P}$, application of readily available water soluble sources of $\mathrm{P}$ fertilizers are more appropriate. Such water-soluble sources are, however, less efficient for upland red and lateritic soils due to high $\mathrm{P}$ fixation. Pattanayak et al. (2011) reported that the unproductive/less productive acid upland soils (Alfisols, Inceptisols, and Entisols) can improve crop yields through application of the right nutrient rates based on soil testing, integrated with organic and inorganic soil ameliorants. $\mathrm{P}$ fertilizer applied at right time showed higher crop yields while improving the efficiency of applied $\mathrm{P}$ in the acidic soils of Odisha. Similarly, Arnall (2014) reported that in acid soils with low $\mathrm{pH}$ conditions, right placement of $\mathrm{P}$ fertilizers through banding helps to alleviate the impact of Al toxicity as phosphate reacts with metals like $\mathrm{Al}$ and $\mathrm{Mn}$ to form insoluble compounds and reduces the harmful effects of the metals on the emerging seedlings.

In India, there are about $49 \mathrm{M}$ ha of soils of which about $25 \mathrm{M}$ ha have $\mathrm{pH}$ less than 5.5 and $2.3 \mathrm{M}$ ha have $\mathrm{pH}$ between 5.6 and 6.5. In these soils, there is an acute deficiency of phosphorus $(\mathrm{P})$ which is the yield limiting nutrient in crop production. These soils are rich in sesquioxides, low in humus and have high $\mathrm{P}$ fixing capacity. In these soils, crops respond to applied $\mathrm{P}$ only after $\mathrm{P}$ fixing capacity of the soils is satisfied, justifying need for high levels of applied $P$ to crop. Rock phosphate (RP) can supply $\mathrm{P}$ at a unit cost much lower than that from other commonly used fertilisers containing water soluble $\mathrm{P}$ and can be used as $\mathrm{P}$ source for agricultural production especially in acid soils. Research on the utilisation of RP as a direct fertiliser, especially in acid soils, has continued in India since the 1970s. In recent years the increase in price of phosphatic fertilizers and environmental pollution, practice of application of rock phosphate is definitely cheap and ecofriendly. The total reserves of rock phosphates in India are around 200M.T (Fertilizer Focus, 1991) comprising station of Andhra Pradesh, Madhya Pradesh, Tamil Nadu, West Bengal, Rajasthan etc. Mostly the indigenous rockphosphates are of low grade (<20\% P2O5) but imported rockphosphates are of high grade $\left(>30 \% \quad \mathrm{P}_{2} \mathrm{O}_{5}\right)$. The efficiency of chemically processed fertilizers is very slow due to chemical fixation and perpetuation making $10-20 \%$ of applied ' $\mathrm{P}$ ' available to the crops. This experiment is an approach to know the direct effect of phosphate rocks in an acidic environment to maize. Maize (Zea mays L.) is an important cereal food crop of the world with highest production and productivity as compared to rice and wheat. Maize is the third most important cereal after rice and wheat for human food by contributing almost $9 \%$ to India's food basket and 5\% to World's dietary energy supply. Its production has increased more than 12 times from a mere 1.73 million tons $1950-51$ to 21.73 million tons in $2014-17$ and presently it occupies 8.55 million hectare area with the mean yield of 9.0 tons/hectare. This achievement is remarkable despites $\sim 75 \%$ maize area is under rainfed and low input condition, which often faces vagaries of monsoon. In India, it is being estimated that maize demand will continue to increase in view of increasing demand in poultry and livestock sectors in the country and growing non vegetarian population and changing food habits. To meet the growing demand, enhancement of maize yield in coming years across all the growing locations in India is the big challenge in the era of climate change. Meeting such challenge will only be possible through science based technological interventions like single cross hybrid technology and application of novel molecular tools and techniques in maize improvement.

\section{Materials and Methods}

The field experiment entitled was conducted at central farm OUAT, Bhubaneswar under, Department of Soil Science \& Agricultural Chemistry during Kharif' 2017. The physiological studies were carried out in the Department of Plant Physiology, College of Agriculture, and Bhubaneswar. The experimental site is located in the Central Farm, OUAT, and Bhubaneswar which lies at $85047^{\prime} 18^{\prime \prime}$ E latitude $20016^{\prime}$ 51 " $\mathrm{N}$ longitudes with an elevation of 25.9 meter above mean sea level. The summer months from March to May / June are hot and humid. The mean minimum and maximum temperature were $22.6{ }^{\circ} \mathrm{C}$ and $32.6{ }^{0} \mathrm{C}$ respectively. Temperatures drop December and January in approximately $15{ }^{\circ} \mathrm{C}$ during these months. The physico-chemical properties of the soil of experimental site were loamy texture with $\mathrm{pH}$ 5.2. The soil had the available Bray's $P 15.68 \mathrm{~kg}$ ha-1 (medium), Available Nitrogen $239 \mathrm{~kg}$ ha-1(low), Available Potassium $150 \mathrm{~kg}$ ha-1 (medium) and Organic carbon $3.4 \mathrm{~g}$ $\mathrm{kg}-1$ Soil. Maize variety PAC-751 was taken for study and the experiment was laid out in a Randomised Block Design with 7 treatments and replicated thrice. All the treatments receives full dose of $\mathrm{N}$ and $\mathrm{K}$ as per the recommended dose of N:P:K (150:50:50) except control. For Maize $\mathrm{P}_{2} \mathrm{O}_{5}$ was applied entirely as basal dose while $\mathrm{N}$ and $\mathrm{K}$ were applied as basal dose and as top dressing at sowing and tasseling stages respectively. Experimental Design and Treatments field experimental design laid out in Randomized Block Design with seven treatment T1 Control, T2 100\% P(RP),T3 100\% $\mathrm{P}(\mathrm{SSP}), \mathrm{T} 475 \% \mathrm{P}(\mathrm{RP})+25 \% \mathrm{P}(\mathrm{SSP}), \mathrm{T} 550 \% \mathrm{P}(\mathrm{RP})+50 \%$ $\mathrm{P}(\mathrm{SSP}), \mathrm{T} 625 \% \mathrm{P}(\mathrm{RP})+75 \% \mathrm{P}(\mathrm{SSP})$ and $\mathrm{T} 7100 \% \mathrm{P}(\mathrm{SSP})+$ Lime@0.2 LR and replicated in thrice times. Shoot dry matter and its partitioning at successive growth stages were calculated by taking two hills from each plot were randomly uprooted at heading and maturity stages for physiological observations. Plant parts such as stem, leaf and panicle were separated. The leaf area was measured by multiplying apparent leaf area (length and maximum breadth) with constant leaf area factor i.e., 0.725 at vegetative stage, 0.80 at maturity (Yoshida, 1981). The plant parts were dried separately in a hot air oven at $90^{\circ} \mathrm{C}$ for 48 hours. The dry weight of different plant parts was recorded at each growth stage and expressed in $\mathrm{g} / \mathrm{m}^{2}$. Then it was ground to powder for further laboratory analysis. Growth Analysis parameters for example Leaf Area Index (LAI) is expressed as the ratio of the leaf area (A) (only one side) to the ground area (P) occupied by the crop (Watson, 1947)

$$
\mathrm{LAI}=\mathrm{A} / \mathrm{P}
$$

Carbohydrate (NSC) content of plant samples was determined by following procedure (Yosidha et al., 2005). $100 \mathrm{mg}$ of 
powdered dry sample was taken into in powder form and extracted using $80 \%$ ethanol (v/v). The exert was then used for sugar analysis by adding anthrone reagent, followed by measurement of absorbance at $630 \mathrm{~nm}$ using a spectophotometre. in case of simple carbohydrate estimation the sample was kept in a boiling tube and hydrolyzed by keeping it in boiling water for three hours with $5 \mathrm{ml}$ of $2.5 \mathrm{~N}$ $\mathrm{HCl}$ and then cooled to room temperature. The sample was neutralized with sodium carbonate till the effervescence ceases and then transferred it to $100 \mathrm{ml}$ volumetric flask and the volume was made up to $100 \mathrm{ml}$. $10 \mathrm{ml}$ of this was taken in a centrifuged tube and was centrifuged for 10 minute. The supernatant was collected and 0.2 to 0.3 aliquots were taken for analysis. $12 \mathrm{ml}$ of anthrone reagent was added and heated for eight minutes in a boiling water bath. The absorbance (OD) of the filtrate was recorded at $630 \mathrm{~nm}$. The quantity of glucose was calculated from the standard curve prepared from glucose stock solution.

Amount of carbohydrate present in $100 \mathrm{mg}$ of the sample $=[(\mathrm{mg}$ sugar from grap $/ \mathrm{ml}$ of aliquot sample $) \times($ Total volume of extract in $\mathrm{ml}$ of sample in $\mathrm{mg}$ )] $\times 100$

The protein content was estimated by Lowry's method and TSS (Total soluble sugar) was estimated by anthrone reagent. The experimental design adopted for this research work was simple randomized block design (RBD).

\section{Results and Discussion}

\section{Growth and morphological traits}

Plant Height: Data on plant height of different maize hybrids grown under different doses of phosphorous application were recorded and presented in Table 1. The height increased progressively after planting and reached its maximum at harvest. Maximum increase evident during $30 \mathrm{DAS}$ and slowly thereafter till harvest. $\mathrm{T}_{7}(100 \% \mathrm{SSP}+0.2 \% \mathrm{LR})$ produced taller plants at harvest stage. Variation in plant height was found among the treatments. The maximum plant height of $(63.95 \mathrm{~cm})$ was recorded in $\mathrm{T}_{7}$ followed by $(57.33$ $\mathrm{cm})$ in $\mathrm{T}_{6}$ at 30DAS and $225.83 \mathrm{~cm}$ in $\mathrm{T}_{7}$ followed by $(220.67 \mathrm{~cm})$ in $\mathrm{T}_{5}$ at 90 DAS. Significant increase in height was recorded in plants supplied with $100 \% \mathrm{SSP}+0.2 \% \mathrm{LR}$ of recommended dose of phosphorous which was applied at sowing of the crop.

Table 1: Effect of different level of Phosphorous on Plant height

\begin{tabular}{|c|c|c|c|}
\hline \multicolumn{2}{|c|}{ Treatment } & 30DAS & 90DAS \\
\hline T1 & Control & 49.82 & 187.33 \\
\hline T2 & 100\% RP & 52.13 & 193.67 \\
\hline T3 & $100 \%$ SSP & 56.33 & 213.00 \\
\hline T4 & $75 \%$ RP+25\% SSP & 56.19 & 207.33 \\
\hline T5 & $50 \%$ SSP+50\% RP & 57.00 & 220.67 \\
\hline T6 & 25\% RP+75\% SSP & 57.33 & 215.67 \\
\hline T7 & 100\% SSP+0.2\% LR & 63.95 & 225.83 \\
\hline \multicolumn{2}{|c|}{ S.E.m $( \pm)$} & 1.338 & 1.338 \\
\hline \multicolumn{2}{|c|}{ C.D.(0.05) } & 1.124 & 1.124 \\
\hline
\end{tabular}

\section{Number of green leaves per plant}

Data on number of green leaves per plant of maize hybrids grown under different doses of phosphorous were indicated in Table 2. The maximum number of green leaves per plant was produced in $T_{7} \& T_{6}$ at 30 DAS which were significantly at par with each other. Number of green leaves significantly increased from 30DAS to 90 DAS. The lowest no of leaves of 6.00 was recorded at $T_{2}$ over control at 30DAS and 7.00 at 90DAS. The highest number of leaves was recorded in $T_{7} . T_{5}$ and $\mathrm{T}_{7}$ was significantly at par with each other at 90DAS.
Table 2: No. of leaves per plant

\begin{tabular}{|c|c|c|c|}
\hline \multicolumn{2}{|c|}{ Treatment } & 30DAS & 90DAS \\
\hline T1 & Control & 6.33 & 7.00 \\
\hline T2 & 100\% RP & 6.00 & 7.33 \\
\hline T3 & $100 \%$ SSP & 7.0 & 9.33 \\
\hline T4 & $75 \%$ RP+25\% SSP & 6.33 & 8.33 \\
\hline T5 & $50 \%$ SSP+50\% RP & 6.67 & 10.33 \\
\hline T6 & 25\% RP+75\% SSP & 7.33 & 10.0 \\
\hline T7 & 100\% SSP+0.2\% LR & 7.33 & 11.33 \\
\hline \multicolumn{2}{|c|}{ S.E.m $( \pm)$} & 0.262 & 0.360 \\
\hline \multicolumn{2}{r}{ C.D.(0.05) } & 0.808 & 1.109 \\
\hline
\end{tabular}

\section{Total dry matter production (g)}

The dry matter production by maize increased progressively as the growth advanced and presented in (Tablem3). Maximum dry matter of $224.8 \mathrm{~g}$ plant-1 was obtained from T7 at 90DAS where as minimum dry matter accumulation (189.66 g /plant) was recorded by at 90 DAS. Application of different level of phosphorous also significantly influenced the total dry matter production at all the growth stages. At 30 DAS, the maximum dry matter production of $25.03 \mathrm{~g}$ plant-1 was recorded in $\mathrm{T}_{7}$ followed by $24.84 \mathrm{~g}$ plant- 1 in $\mathrm{T}_{6}$.

Table 4: Dry Weight After Harvest (G)

\begin{tabular}{|c|c|c|}
\hline Treatment & 30DAS & 90DAS \\
\hline $\mathrm{T} 1$ & 18.05 & 189.66 \\
\hline $\mathrm{T} 2$ & 18.81 & 201.28 \\
\hline $\mathrm{T} 3$ & 22.20 & 215.95 \\
\hline $\mathrm{T} 4$ & 21.64 & 204.02 \\
\hline $\mathrm{T} 5$ & 21.47 & 219.94 \\
\hline $\mathrm{T} 6$ & 24.84 & 218.94 \\
\hline $\mathrm{T} 7$ & 25.03 & 221.18 \\
\hline S.E.m $( \pm)$ & 0.808 & 2.589 \\
\hline C.D. $(0.05)$ & 2.489 & 7.976 \\
\hline C.V. & 6.317 & 2.129 \\
\hline \multicolumn{2}{|l}{}
\end{tabular}

\section{Physiological Traits}

\section{LAI}

Leaf area index (LAI) at both 30 DAS and 90 DAS were depicted in table- 5. Data on leaf area index of different Phosphorous management practice revealed that LAI increases from 30DAS to 90 DAS. LAI varied among the treatments. Maximum LAI among all the treatments was recorded in application of $100 \% \mathrm{SSP}+0.2 \% \mathrm{LR}\left(\mathrm{T}_{7}\right)$ followed by application of $25 \% \mathrm{RP}+75 \% \mathrm{SSP}\left(\mathrm{T}_{6}\right)$ at $90 \mathrm{DAS}$. The highest LAI was (1.75) in $\mathrm{T}_{7}$ and lowest (1.33) over control in $\mathrm{T}_{1}$ was recorded at $30 \mathrm{DAS}$. The highest LAI was (3.21) in $\mathrm{T}_{7}$ followed by (3.00) in $\mathrm{T}_{5}$ and lowest (1.97) in $\mathrm{T}_{2}$ over control recorded was recorded at 90 DAS. Significant increase in LAI at both 30DAS and 90DAS were observed.

Table 5: LAI at 30 DAS and 90 DAS

\begin{tabular}{|c|c|c|}
\hline Treatment & 30DAS & 90DAS \\
\hline T1 & 1.30 & 1.84 \\
\hline T2 & 1.33 & 1.97 \\
\hline T3 & 1.64 & 2.64 \\
\hline T4 & 1.53 & 2.33 \\
\hline T5 & 1.67 & 3.00 \\
\hline T6 & 1.71 & 2.89 \\
\hline T7 & 1.75 & 3.21 \\
\hline S.E.m( $( \pm)$ & 0.053 & 0.102 \\
\hline C.D.(0.05) & 0.163 & 0.315 \\
\hline & 5.984 & 6.944 \\
\hline
\end{tabular}




\section{CGR, RGR and NAR}

Crop growth rate(CGR), Relative Growth Rate (RGR) and Net Assimilation Rate (NAR) determined between 30DAS to 90 DAS were depicted in table-6. CGR varied among the treatments ranging a minimum of $17.16 \mathrm{~g} / \mathrm{m}^{2} /$ day to a maximum of $19.93 \mathrm{~g} / \mathrm{m}^{2} /$ day. Among the treatments the highest CGR was recorded in $\mathrm{T}_{7}$ where maize grown with $100 \% \mathrm{SSP}+0.2 \% \mathrm{LR}$ and the lowest CGR was recorded inT2 over control. An increase in CGR was also observed with increase in availability of phosphorous. Significant increase in CGR was recorded at $100 \% \mathrm{SSP}+0.2 \% \mathrm{LR}\left(\mathrm{T}_{7}\right), 50 \% \mathrm{SSP}$ $\left(\mathrm{T}_{3}\right), 25 \% \mathrm{P}(\mathrm{RP})+75 \% \mathrm{P}(\mathrm{SSP})$ and $50 \% \mathrm{P}(\mathrm{RP})+50 \% \mathrm{P}$ (SSP) which were found at par. Significantly higher CGR were recorded in maize crop applied with $100 \% \mathrm{SSP}+0.2 \%$ LR as compared the control. RGR increased with increase in level of Phosphorous availability to the plant. The lowest RGR (41.94 mg/g/day) was recorded in maize crop grown in $\left(\mathrm{T}_{2}\right)$ over control and highest RGR (46.22 mg/g/day) was recorded in plants applied with $100 \% \mathrm{SSP}+0.2 \% \mathrm{LR}\left(\mathrm{T}_{7}\right)$ followed by $50 \% \mathrm{RP}+50 \% \mathrm{SSP}\left(\mathrm{T}_{5}\right)$. Among the combination of Rock Phosphate and Single Super Phosphate, $\mathrm{T}_{5}$ registered the higher RGR than its sole application of $100 \%$ P (RP).

Net assimilation rate varied among the treatments ranging a minimum of $6.22 \mathrm{~g} / \mathrm{m}^{2} /$ day in $T_{7}$ to a maximum value of 9.33 $\mathrm{g} / \mathrm{m}^{2} /$ day in $\mathrm{T}_{1}$. Among the combined application of Rock Phosphate and SSP maximum NAR was recorded in single application of $100 \% \mathrm{P}(\mathrm{RP})$ in $\mathrm{T}_{2}$ and minimum NAR was recorded in $50 \% \mathrm{P}(\mathrm{RP})+50 \% \mathrm{P}(\mathrm{SSP}) . \mathrm{T}_{1}$ and $\mathrm{T}_{2}$. Were significantly at par with each other.

Table 6: CGR, RGR and NAR

\begin{tabular}{|c|c|c|c|}
\hline Treatment & $\begin{array}{c}\text { CGR }\left(\mathbf{g} / \mathbf{m}^{2} / \mathbf{d a y}\right) \\
\text { from 30-90 days }\end{array}$ & $\begin{array}{l}\text { RGR }(\mathbf{m g} / \mathbf{g} / \mathbf{d a y}) \\
\text { from 30-90 days }\end{array}$ & NAR(g/m $\mathbf{2} / \mathbf{d a y})$ \\
\hline $\mathrm{T} 1$ & 17.16 & 35.79 & 9.33 \\
\hline $\mathrm{T} 2$ & 18.24 & 41.94 & 9.31 \\
\hline $\mathrm{T} 3$ & 18.25 & 41.89 & 7.86 \\
\hline $\mathrm{T} 4$ & 19.37 & 42.62 & 7.37 \\
\hline $\mathrm{T} 5$ & 19.49 & 43.98 & 6.52 \\
\hline $\mathrm{T} 6$ & 19.45 & 41.38 & 6.78 \\
\hline $\mathrm{T} 7$ & 19.93 & 46.22 & 6.22 \\
\hline S.E.m( \pm ) & 0.250 & 0.675 & 0.279 \\
\hline C.D.(0.05) & 0.771 & 2.080 & 0.859 \\
\hline C.V. & 2.299 & 2.757 & 6.335 \\
\hline
\end{tabular}

\section{Biochemical Analysis \\ Chlorophyll content}

The chlorophyll content of leaves was measured at 30DAS and at 90DAS and result was registered in (Table-7). From the data it was revealed that irrespective of treatments higher chlorophyll content recorded at 30DAS than at 90DAS. Maximum chlorophyll content was recorded in $\mathrm{T}_{5}(50 \%$ $\mathrm{RP}+50 \%$ SSP) i.e. $2.95 \mathrm{mg} / \mathrm{g}$ of fresh weight followed by $\mathrm{T}_{7}$ $(100 \% \mathrm{SSP}+0.2 \% \mathrm{LR})$ and minimum in $\mathrm{T}_{2}$ at $30 \mathrm{DAS}$. Among the combined application of RP and SSP more chlorophyll content was found in $T_{5}$ followed by $T_{6}$ and minimum in $\mathrm{T}_{2}$. At 90DAS maximum value was found in $\mathrm{T}_{7}$ $(100 \% \mathrm{SSP}+0.2 \% \mathrm{LR})$ followed by $\mathrm{T}_{5}(50 \% \mathrm{RP}+50 \% \mathrm{SSP})$ and minimum in $\mathrm{T} 2$ over control. At 90 DAS there was significant increase in chlorophyll content from maximum to minimum but significant difference was noticed in $\mathrm{T}_{5}$ and $\mathrm{T}_{6}$.
Table 7: Chlorophyll Content

\begin{tabular}{|c|c|c|}
\hline Treatment & At knee height & At harvest \\
\hline T1 & 1.83 & 0.95 \\
\hline T2 & 2.31 & 1.10 \\
\hline T3 & 2.64 & 1.05 \\
\hline T4 & 2.62 & 1.10 \\
\hline T5 & 2.95 & 1.31 \\
\hline T6 & 2.75 & 1.20 \\
\hline T7 & 2.80 & 1.68 \\
\hline S.E.m( $( \pm)$ & 0.130 & 0.060 \\
\hline C.D. $(0.05)$ & 0.400 & 0.186 \\
\hline C.V. & 8.801 & 8.718 \\
\hline
\end{tabular}

\section{Carbohydrate, Protein and Sugar\% in Grain}

Carbohydrate, protein and sugar content in maize grain varied among the treatments. Irrespective of treatment the percent of carbohydrate is more as compared to protein than sugar represented in table-8. The lowest carbohydrate content $(60.97 \%)$, was recorded in $\mathrm{T} 2$ over control and the highest carbohydrate $(65.29 \%)$ was recorded in $\mathrm{T}_{7}(100 \% \mathrm{SSP}+0.2 \%$ LR) followed by $\mathrm{T}_{5}(50 \% \mathrm{RP}+50 \% \mathrm{SSP})$ of $61.37 \%$. Carbohydrate content of grain significantly increased from highest in $\mathrm{T}_{7}$ to lowest in $\mathrm{T}_{2}$ value. But no significant difference was observed between $\mathrm{T}_{7}, \mathrm{~T}_{6}, \mathrm{~T}_{5} \& \mathrm{~T}_{3}$

Protein content of grain differs significantly among the treatments. The lowest protein content $(10.2 \%)$ was recorded in $\mathrm{T} 2$ over control and the highest protein $(11.0 \%)$ was recorded in $\mathrm{T}_{7}(100 \% \mathrm{SSP}+0.2 \% \mathrm{LR})$ followed by $\mathrm{T}_{5}(50 \%$ $\mathrm{RP}+50 \% \mathrm{SSP})$ of $10.53 \%$. Protein content of grain significantly increased among all the treatments. Sugar content of $T_{5}$ and $T_{7}$ were significantly at par with each other. Maximum sugar content (1.20\%) was recorded in $\mathrm{T}_{5}$ followed by (4.00) in $\mathrm{T}_{7}$. The maximum sugar content of grain among the combination of RP and SSP, was recorded in $\mathrm{T}_{5}$ followed by $\mathrm{T}_{6}$.

Table 8: Carbohydrate, protein and sugar content of grain in (\%)

\begin{tabular}{|c|c|c|c|}
\hline Treatment & Carbohydrate (\%) & Protein(\%) & Sugar(\%) \\
\hline T1 & 60.33 & 9.42 & 3.10 \\
\hline T2 & 60.97 & 10.20 & 3.17 \\
\hline T3 & 64.03 & 10.20 & 3.13 \\
\hline T4 & 62.33 & 10.07 & 3.53 \\
\hline T5 & 61.37 & 10.53 & 1.20 \\
\hline T6 & 63.04 & 10.43 & 3.73 \\
\hline T7 & 65.29 & 11.00 & 4.00 \\
\hline S.E.m( \pm$)$ & 0.839 & 0.149 & 0.096 \\
\hline C.D.(0.05) & 2.586 & 0.460 & 0.296 \\
\hline C.V. & 2.309 & 2.519 & 1.698 \\
\hline
\end{tabular}

\section{Nutrient Content By shoot}

$\mathrm{N}, \mathrm{P}$ and $\mathrm{K}$ content the shoot (Leaf \& stem) and the seed was presented in table- 9 . $\mathrm{N}$ content in plant was influenced by availability of Phosphorous in soil. The variation in $\mathrm{N}$ content in the plants varied among the treatments in the range of $0.69 \%$ to $1.40 \%$ in the shoot and 1.66 to $2.06 \%$ in grain respectively. The highest value of $\mathrm{N}$ was recorded in $\mathrm{T}_{7} . \mathrm{N}$ content in the stover and the grain increased with increase in level of Phosphate application but significant increase over control was recorded in $\mathrm{T} 7(100 \% \mathrm{SSP}+0.2 \% \mathrm{LR})$ and $\mathrm{T}_{5}$ (50\% RP+50\% SSP). However, no significant difference was 
noticed in $\mathrm{N}$ content in the grain among the different combination of RP \& SSP but significant difference was noticed $\mathrm{N}$ content in shoot. The content of $\mathrm{P}$ in the shoot and seed was influenced by the different levels of application of phosphorous. The variation recorded among the treatments for $\mathrm{P}$ concentration. was in the range of $0.37 \%$ to $0.55 \%$ in grain and $0.33 \%$ to $0.52 \%$ in maize Stover respectively. Among the treatments, the maximum $\mathrm{P}$ content in grain and Stover was found in $\mathrm{T}_{7}$. Among the combined application of RP and SSP $\mathrm{T}_{4}, \mathrm{~T}_{5}$ and $\mathrm{T}_{6}$ were at par with each other. The $\mathrm{K}$ content varied among the treatments in the range of $1.19 \%$ to $1.81 \%$ in the grain and $0.45 \%$ to $0.73 \%$ in stover respectively. The highest $\mathrm{K}$ content was recorded in $\mathrm{T}_{7}$. Significant increase was recorded in plants supplied $100 \%$ SSP $+0.2 \%$ LR and $50 \% \mathrm{RP}+50 \% \mathrm{SSP}$. There is no significant difference was recorded among the different combination of RP \& SSP in the stover. Sulphur content of plant varied in stover and grain. In stover sulphur content varied from $\mathrm{T}_{1}$ to $\mathrm{T}_{7}$ significantly in the range of $1.19 \%$ to $1.8 \%$ minimum to maximum respectively. In stover the range varies from $0.45 \%$ to $0.73 \%$ minimum to maximum respectively.

\section{Nutrient content of plant (\%)}

Nutrient content by plant and plant parts at harvest revealed that concentration of $\mathrm{N}, \mathrm{P}$ and $\mathrm{K}$ was more by grain than stover and total uptake of $\mathrm{N}>\mathrm{K}>\mathrm{P}$ in all the treatments. Concentration of N, P and $\mathrm{K}$ by maize plant and its parts was influenced by the level of phosphorous application. Content of these three major nutrients increases with increase in level of $\mathrm{P}$ application but significant increase over control was observed was observed at $100 \% \mathrm{SSP}+0.2 \% \mathrm{LR}$ and $50 \%$ $\mathrm{RP}+50 \% \mathrm{SSP}$. Among the different combination of RP and SSP treatments the highest content of $\mathrm{N}, \mathrm{P}$ and $\mathrm{K}$ in plant parts was recorded in maximum value was recorded in $\mathrm{T}_{5}$ over the sole application of RP in Stover but in grain highest $\mathrm{N}, \mathrm{P}$ \& $\mathrm{K}$ content was recorded in $\mathrm{T}_{6}$. Sulphur content of plant varied in Stover and grain. In Stover sulphur content varied from $T_{1}$ to $T_{7}$ significantly Phosphorus is a component of nucleic acids and lipids and is important in the production and transport of sugars, fat and protein during sugar beet production. Phosphorus is especially important during early root development. A good supply of phosphorus ensures rapid root growth and good uptake of other nutrients, Masood et al. (2013). A good and optimum supply of P is associated with increased root growth due to which the plants explore more soil nutrients and moisture. That is why the grain yield was the lowest in the control plots because lack of $\mathrm{P}$ deteriorated the roots growth of the plants which negatively affected the other physiological functions of the maize plants in the control plots. Maqsood et al. (2013). Effect of phosphorus levels on the yield and yield components of maize. At harvest stage, the grain $\mathrm{P}$ content was much higher than that of the shoot. This may be due to the translocation of phosphorus from shoot to grain at the harvest stage (Hedley et al., 1994). Uptake of all the macro and micronutrients increased with increasing $\mathrm{P}$ levels, indicating increase in dry weight of crop species with increasing P levels, Fageria et al., (2013.) Sulfur (S) is a building block of protein and a key ingredient in the formation of chlorophyll. Crops cannot reach their full potential in terms of yield or protein contents without adequate sulfur (Zhao, 1999). Growth of maize is sensitive to sulfur deficiency because it decreases grain size under sulphur limiting condition. Sulfur has beneficial effects by lowering soil $\mathrm{pH}$ and improving physical condition of the soil (Choudry and Das, 1996). Grain yield enhance with rising quantities of both sulfur and nitrogen and when soil is deficient in sulfur, full yield potential of the crop cannot be realized regardless of other nutrients (Tandon, 1984). The nutrition value of cereals is also determined by the proportion of $\mathrm{S}$ containing amino acids (Katyal, 1987). Phosphorus interacts with sulfur as phosphate ion is more strongly bond than sulphate (Hedge and Murthy, 2005). The application of phosphorous fertilizer results in increased anion adsorption sites, which releases sulphate ions into the solution (Tiwari and Gupta, 2006).

Table 9: Nutrient content in grain

\begin{tabular}{|c|c|c|c|c|c|c|c|c|}
\hline \multirow{2}{*}{ Treatment } & \multicolumn{2}{|c|}{ N\% } & \multicolumn{2}{|c|}{ P\% } & \multicolumn{2}{|c|}{ K\% } & \multicolumn{2}{|c|}{ S\% } \\
\hline & Grain & Stover & Grain & Stover & Grain & Stov & Grain & Stor \\
\hline T1 & 1.66 & 0.69 & 0.37 & 0.60 & 0.63 & 0.33 & \begin{tabular}{|l|}
1.19 \\
\end{tabular} & 0.45 \\
\hline $\mathrm{T} 2$ & 1.73 & 1.02 & .38 & 0.71 & .89 & 0.3 & 1.32 & 0.50 \\
\hline 1 & 1.84 & & & & & & 99 & \\
\hline$T^{2}$ & 75 & 1. & & 0. & 09 & & 1.56 & \\
\hline T5 & 1.96 & 1. & 49 & 1.09 & 0.97 & 44 & \begin{tabular}{|l|}
1.64 \\
\end{tabular} & 0.61 \\
\hline $\mathrm{Tt}$ & .0 & 1.0 & 0.53 & 0.87 & 1.16 & 0. & \begin{tabular}{|l|}
1.67 \\
\end{tabular} & 0.57 \\
\hline $\mathrm{T}$ & 2.06 & 1.4 & 5 & 1. & 1.33 & 0. & \begin{tabular}{|l|}
1.81 \\
\end{tabular} & 0.73 \\
\hline $\mathrm{F}$ & 086 & .035 & 4 & 0.010 & .132 & 0.026 & 0.077 & 0.0 \\
\hline D. (0.05) & 0.265 & 0.109 & 0.122 & 0.032 & 0.407 & 0.081 & 0.236 & 0.035 \\
\hline$\cdot v$ & 8.014 & 5.465 & 15.33 & 1.117 & 6.18 & $11.4 \mathrm{C}$ & 8.638 & 3.372 \\
\hline
\end{tabular}

\section{Yield \& Yield attributing characters} Yield attributing characters

Yield attributing characters were presented in table -10. Cob weight varied among the treatments. The highest cob weight (103.63g) was recorded in $\mathrm{T}_{7}(100 \% \mathrm{SSP}+0.2 \% \mathrm{LR})$. Significant increase in cob weight was noticed among the other treatments. Number of grains per cob increased significantly with increase in application of different doses of phosphorous. Number of graing per cob was found highest in $\mathrm{T}_{7}$ followed by $\mathrm{T}_{5}$ differ significantly. Highest number of seed (103.6) was recorded in $T_{7}$ and lowest number of seed (81.4) was recorded in $\mathrm{T}_{2}$ over control. Variation in number of row per cob was noticed among the treatments. The highest no. of row (18) was recorded in $\mathrm{T}_{7}(100 \% \mathrm{SSP}+0.2 \% \mathrm{LR})$ and lowest was (12) recorded in $T_{4}, T_{2}$ and $T_{1}$. Significant increase in no. of rows per cob was obtained with increase in the levels of application of P (SSP)applied. Different dose of Phosphorous significantly influenced the number of cob length presented in $T_{7}$ recorded the maximum mean cob length $(24.93 \mathrm{~cm})$ whereas $\mathrm{T}_{2}$ had the minimum cob length $(22.83 \mathrm{~cm})$ over control. Significant increase in cob length was recorded with the application of $100 \% \mathrm{SSP}+0.2 \%\left(\mathrm{~T}_{7}\right) \mathrm{LR}$ followed by application of $50 \% \mathrm{RP}+50 \% \quad \mathrm{SSP}\left(\mathrm{T}_{5}\right)$. No significant difference was recorded among the different combination of RP and SSP. Cob diameter varied significantly with regards to different dose of phosphorous application presented in (Table 4.). Application of $100 \%$ $\mathrm{SSP}+0.2 \% \mathrm{LR}\left(\mathrm{T}_{7}\right)$ produced the thickest cob among all the treatments. $\mathrm{T}_{7}$ recorded significantly thickest cob with diameter of $1.59 \mathrm{~cm}$ followed by $\mathrm{T}_{3}$ while $\mathrm{T}_{2}$ produced the thinnest cob $1.2 \mathrm{~cm}$ diameter over the control. Variation in 100 seed weight was noticed among the treatments. The highest test weight was $(30.51 \mathrm{~g})$ and the lowest was (29.23g) were recorded in $\mathrm{T}_{7}$ and $\mathrm{T}_{2}$ respectively. Significant increase in test weight was obtained with increase in dose of $\mathrm{P}$ application but among the combined application of RP \& SSP, $\mathrm{T}_{5}$ and $\mathrm{T}_{6}$ were significantly at par with each other. 
Table 10: Yield and yield attributing characters

\begin{tabular}{|c|c|c|c|c|c|c|}
\hline Treatment & $\begin{array}{c}\text { Cob } \\
\text { weight }\end{array}$ & $\begin{array}{c}\text { No. of } \\
\text { seeds per } \\
\text { cob }\end{array}$ & $\begin{array}{c}\text { No. of } \\
\text { row per } \\
\text { cob }\end{array}$ & $\begin{array}{c}\text { Cob } \\
\text { length }\end{array}$ & $\begin{array}{c}\text { Cob } \\
\text { diameter }\end{array}$ & $\begin{array}{c}\mathbf{1 0 0} \text { seed } \\
\text { weight }\end{array}$ \\
\hline T1 & 67.72 & 415.33 & 12.00 & 20.65 & 1.16 & 24.90 \\
\hline T2 & 81.41 & 462.00 & 12.00 & 22.83 & 1.20 & 26.93 \\
\hline T3 & 94.98 & 481.67 & 14.00 & 23.37 & 1.57 & 28.17 \\
\hline T4 & 86.94 & 472.00 & 12.00 & 23.18 & 4.03 & 27.66 \\
\hline T5 & 97.6 & 526.33 & 16.00 & 23.90 & 1.34 & 29.33 \\
\hline T6 & 91.71 & 497.67 & 16.00 & 23.71 & 1.33 & 28.53 \\
\hline T7 & 103.63 & 530.67 & 18.00 & 24.93 & 1.59 & 30.51 \\
\hline S.E.m( \pm ) & 1.247 & 12.535 & 0.563 & 0.267 & 0.073 & 0.284 \\
\hline C.D.(0.05) & 3.841 & 38.626 & 1.736 & 0.823 & 0.224 & 0.875 \\
\hline C.V. & 2.411 & 1.489 & 6.831 & 1.992 & 2.915 & 1.757 \\
\hline
\end{tabular}

\section{Harvest Index}

Maize crop with different dose of phosphorous influenced the grain yield significantly presented in (Table 1.). Among the different treatments, $T_{7}$ recorded the highest yield $\left(7.22 \mathrm{t} \mathrm{ha}^{-1}\right)$ followed by $T_{5}\left(7.18 \mathrm{tha}^{-1}\right)$ and were significantly at par with each other. The treatment $T_{2}$ recorded the minimum grain yield of $5.43 \mathrm{t} \mathrm{ha}^{-1}$ over the control. The treatment $\mathrm{T}_{5}$ and $\mathrm{T}_{6}$ differ significantly among the different combination of RP and SSP. Harvest Index varied among the treatments. The highest $\mathrm{HI}(43.52 \%)$ was recorded in $\mathrm{T}_{7}$ among the treatments. Increase in phosphorous dose significantly increased the $\mathrm{HI}$ in $\mathrm{T}_{7} \& \mathrm{~T}_{5}$ respectively over the control. Among the combination of RP and SSP, $\mathrm{T}_{6}$ and $\mathrm{T}_{5}$ are significantly at par with each other.

Table 11: Harvest Index

\begin{tabular}{|c|c|c|}
\hline Treatment & Yield (t/ha) & HI\% \\
\hline T1 & 4.75 & 31.14 \\
\hline T2 & 5.43 & 35.92 \\
\hline T3 & 6.52 & 40.37 \\
\hline T5 & 6.27 & 38.11 \\
\hline T6 & 7.18 & 42.31 \\
\hline T7 & 6.60 & 41.16 \\
\hline S.E.m( \pm$)$ & 7.26 & 43.52 \\
\hline C.D.(0.05) & 0.186 & 0.423 \\
\hline C.V. & 0.572 & 1.303 \\
\hline
\end{tabular}

Table 12: Correlation between growth and yield attributing characters with grain yield

\begin{tabular}{|c|c|}
\hline Characters & Correlation co-efficient (r) \\
\hline Plant height & 0.943801 \\
\hline No.of leaves & 0.90769 \\
\hline Dry weight & 0.959966 \\
\hline LAI & 0.909711 \\
\hline Chlorophyll & 0.779848 \\
\hline Carbohydrate & 0.916304 \\
\hline Protein & 0.968037 \\
\hline Sugar & 0.800878 \\
\hline Cob weight & 0.999993 \\
\hline No. of Seeds per cob & 0.903325 \\
\hline No.of row per cob & 0.842295 \\
\hline Cob length & 0.990181 \\
\hline Cob diameter & 0.746024 \\
\hline 100 seed weight & 0.990118 \\
\hline
\end{tabular}

\section{Correlation studies}

Correlation studies were undertaken to determine the degree of association between yield and yield attributing characters of maize and the $r$ values are presented in Table 12. The grain yield was positively correlated with all the yield attributing characters. Growth characters viz., plant height at harvest, leaf area index at 60 DAS and dry matter accumulation were positively correlated with grain yield.

\section{References}

1. Phosphorus Availability in Low-P and Acidic Soils as Affected by Liming and $\mathrm{P}$ Addition $V$. Antoniadis, F. Hatzis, D. Bachtsevanidis \& S. D. Koutroubas; Communications in Soil Science and Plant Analysis. 2015; 46(10):1288-1298

2. Effect of Levels of Phosphorus and Sulphur on Growth, Yield and Quality of Sesame (Sesamum indicum L.) R I Shelke; N K Kalegore; K P Wayase World Journal of Agricultural Sciences. 2014; 10(3):108-111.

3. Radiation-Use Efficiency, Net Assimilation Rate and Thermal Integral as a Function of Phosphorus in Maize (Zea mays L.) DazLpez Ernesto; J Loeza Corte; EMorales Rosales Edgar J; DomnguezLpez Aurelio; FrancoMora Omar Agrociencia. 2013; 47(2):135-146.

4. Effect of Nitrogen and Phosphoruos On Growth, Flowering, Fruiting and Yield of Tomato (Lycopersicon esculentum MILL.) M L Meena; K Ravendra; R B Ram; Progressive Horticulture. 2012; 44(2):727-739.

5. Supplementary Phosphorus can Alleviate Boron Toxicity in Tomato Cengiz Kaya; A Levent Tuna; M Dikilitas;A Muhhamed; Scientia Horticulturae. 2009; 121(3):284-288

6. Integrated Phosphorus Management in Maize (Zea mays)-Sunflower (Helianthus annuus)- Cowpea (Vigna unguiculata) Fodder Cropping System

7. Kumaresn MA, TN Balasubramanian Indian Journal of Agronomy, 2001, 46(3).

8. Establishment of the Critical Limit of SoilAvailable Phosphorous for Maize Production in Low Acidic Ultisols of West Africa B V Bado; F Lompo; Communications in Soil Science and Plant Analysis. 2010; 41(8):968-976.

9. Crop (Maize) Response to Direct Application of Local Phosphate Rock on Selected Acid Soils of Tanzania; M M Msolla; J M R Semoka; C Szilas; Communications in Soil Science and Plant Analysis. 2007; 38(1-2):93-106.

10. Effect of Nitrogen and Phosphorous on Grain Yield of Hybrid Maize (Zea mays L.) M Yakadri; T Rmesh; B Vijay Kumar; Agricultural Science Digest, 2001, 21. 